\title{
Exploration on Mode and Mechanism of "Five-dimensional Force Drive and Collaborative Education" for Applied Chemistry Majors
}

\author{
Jun Wang* ${ }^{*}$ Zheng-Hao Fei Jian-Qing Tao \\ School of Chemistry and Environmental Engineering, Yancheng Teachers University, No. 2, Hope Avenue \\ South Road, Jiangsu 224007, China
}

\begin{abstract}
In order to adapt to the local economic development needs of Jiangsu province, especially Yancheng city, the applied chemistry major of Yancheng Teachers University constructed the teaching system with deep integration of theory and practice and strengthened the cultivation of the students' knowledge application ability, practical ability, professional position ability and innovation and entrepreneurship ability based on the demand orientation. Furthermore, the applied chemistry major of Yancheng Teachers University explored and built the mechanism of the five-dimensional force drive and collaborative education mode for universities, local governments, enterprises, industries and research institutes, significantly enhancing students' entrepreneurial innovation and engineering practice ability, and achieving the coordination and balance between the supply side and the industry demand side of talent cultivation.
\end{abstract}

Keywords: Five-dimensional, Collaborative education mode, School-local government cooperation, Schoolenterprise cooperation, School-institutes cooperation

DOI: $10.7176 / \mathrm{JEP} / 10-12-22$

Publication date: April $30^{\text {th }} 2019$

\section{Introduction}

Keeping educating people first and improving the quality of applied talents is the essential requirement and fundamental mission of higher education. Based on the community of Tonys and Haken's cooperative learning theory and the goal of cultivating high-quality talents for the country, the applied chemistry major of Yancheng Teachers university fully implemented the new requirements of collaborative innovation and collaborative education, and have built the new five-dimensional collaborative education system for universities, local governments, enterprises, industries, and research institutes ${ }^{[1-3]}$. By the new five-dimensional collaborative education system, we promoted close cooperation between various educational systems and established the cooperative education mechanism of resource sharing, complementary advantages and collaborative development to improve the quality of talent cultivation and local economic and social development.

2. Constructing the new "Five-dimensional Force Drive" collaborative education system for universities, local governments, enterprises, industries and research institutes

Following the education theory and the law of human growth and development and serving the Yancheng local economy and social development as the foothold with the university as the main body, the applied chemistry major of Yancheng Teachers University carried out supply-side reforms and built a new Five-dimensional Force Drive and Collaborative Education System to bring together universities, local governments, enterprises, industries and research institutes. Among them, "Five-dimensional Force Drive" refers to the cooperation and cooperation between universities, local governments, enterprises, industries and research institutes.

\subsection{Taking the talent cultivation as the combination point, established a new Five-dimensional Force Drive and Collaborative Education System for universities, local governments, enterprises, industries and research institutes Talent cultivation is the fundamental task of universities. Local governments have macro management and regulation functions for the education quality of university and talents demand. Enterprises, industries and research institutes are the main employment bases for university graduates and the source of feedback on the quality of training ${ }^{[4]}$. Among the above-mentioned five parties, universities are the mainstays, meanwhile, local governments, enterprises, industries and research institutes are synergistic, and the combination is talent cultivation. Based on the aforementioned relationship between universities and local governments, enterprises, industries and research institutes, the applied chemistry major of Yancheng Teachers Universities constructed a new Five-dimensional Force Drive and Collaborative Education System for the cultivation of talents in universities, local governments, enterprises, industries and research institutes.}

2.1.1. Collaboration between schools and governments to cultivate students' practical, innovative and entrepreneurial abilities

The applied chemistry major of Yancheng Teachers University has been successfully supported by the Flagship 
Major Development of Jiangsu Higher Education Institutions (received provincial education department funding of 9.6 million yuan), the provincial "Chemical Engineering and Technology Comprehensive Training Center" platform project in Jiangsu Province (received provincial education department funding of 2 million yuan), the central financial development special fund "Chemical Engineering and Technology Experimental Teaching Platform" construction project, the Jiangsu Local Education Additional Project and other supports. The total investment is nearly 15 million yuan, which greatly improved the teaching infrastructure of the applied chemistry major.

2.1.2. School-enterprise association to expand school resources and construct high-level "double-quality teacher" teaching body

The applied chemistry major of Yancheng Teachers University combined with enterprises to create a regional education alliance, sharing resources such as corporate premises, capital, research and development equipment to train students and teachers. The applied chemistry major of Yancheng Teachers University cooperated with Jiangsu Huifeng Agrochemical Co., Ltd., Jiangsu Dahua Chemical Industry Co., Ltd., Yancheng Yueda Dongfang Automobile Industry Development and Investment Co., Ltd. to build off-campus practice teaching bases.

The applied chemistry major of Yancheng Teachers University cooperated with the chemical enterprises to set up a team of full-time and part-time teachers. On the one hand, the part-time teachers from the front line of enterprises were selected to take practical skills courses, forming a well-structured "double-quality teacher" teaching team composed of full-time teachers of Yancheng Teachers University and technical experts (part-time teachers) from the co-operative enterprises. On the other hand, the teaching level of teaching team has been improved. For full-time teachers with lack of practical experience and high level of theoretical knowledge and academic qualifications, the focus is on improving their practical ability. The applied chemistry major of Yancheng Teachers University followed the guiding ideology of "taking professional competence as the standard, engineering and learning as the means, and enterprises to participate in the guidance" to reach a zero-distance contact cooperation model with the enterprise and to create a large number of opportunities for full-time teachers to participate in enterprise technological transformation projects and enhance their practical ability. Finally, the level of part-time teachers has been improved. The training of part-time teachers is mainly to enhance their educational and teaching ability, encourage them to continue their studies, and strengthen their theoretical foundation. In addition, mutual help between the part-time teachers has been encouraged to improve the teaching level of part-time teachers.

The research and development community with enterprises and the applied chemistry major of Yancheng Teachers University has been built to jointly carry out scientific and technological breakthrough. Experts and professors with practical experience has been selected to help local enterprises develop new products, promote local economic development, and improve the enthusiasm of local governments, enterprises, industries and research institutes to participate in collaborative education.

2.2. Taking the comprehensive development of students as the goal, established a new education model that cognition, skills, and emotions could be developed in a well-coordinated manner through overall planning

2.2.1. Guided by professional ability training, constructed a scientific curriculum system

A scientific curriculum system has been constructed based on the cultivation of students' professional ability by Yancheng Teachers University. The newly constructed curriculum system is mainly composed of general education course, subject platform course, professional course, innovation and entrepreneurship course, cross and personality development course, and concentrated practice course, which reflected the well-coordinated development of cognition, skill and emotion. The needs of local enterprises and industries have been transform into talent cultivation objectives, professional basic requirements, training specifications, and courses in the abovementioned curriculum system. The curriculum system reform mainly consists of the following aspects: First, the professional curriculum is optimized, and the subject professional knowledge system is more perfect by negotiating with the enterprises. The second is to compress the theoretical teaching credits in the class, increase the proportion of extracurricular concentrated practice teaching, and focus on the off-campus professional trainee, professional internships, and innovative entrepreneurial practice activities, which account for $20-30 \%$ of the total credits, to guarantee the opportunities and hours of students' enterprise practice from the perspective of system. The third, according to the two major categories of natural sciences and humanities and social sciences, we add cross-cutting and personality development courses and require all students to choose 8 credits each other to make up for the lack of courses in the traditional Chinese culture and humanities development of engineering majors. 2.2.2. Guided by practical ability training, built a "four-level, four-mode, four-platform" multi-dimensional practical teaching system and model

The "four levels" means to optimize the content and mode of practical teaching according to the "basic experimentcomprehensive training-practical training-innovation and entrepreneurship". At the same time, the old content that does not meet the social and economic development has been eliminated, and the teaching content of new technologies and new techniques has been greatly increased. 
The "four-mode" means to implement the experimental teaching mode of "first-sense awareness and solid foundation". By strengthening the students' basic knowledge, teachers and students jointly develop experimental plans, analyze experimental results to improve experimental teaching effects and consolidate students' basic experimental ability. Implementation of the "virtual and real combination, four-in-one" comprehensive training mode, which relies on the provincial online open virtual simulation experimental teaching platform to carry out simulation training with simulation equipment, achieve the effect of virtual and real combination. Meanwhile, the system also relies on the school micro-factory to make practical teaching business, make the instrument operation visible, make the operating control diversified and make the training project comprehensive. In this way, we can solve the problems of unsystematic field practice and cultivate students' professional and technical skills. The practical training model of "entering enterprises into school, integrating production and education" is guided by industrial demand and aims to co-construct a school-enterprise engineering design platform with enterprises. In order to train students' engineering practice ability, practical production problems have been taken as research objects and carried out as case teaching through the practical training model. Following the "task-driven, competitive carrier" innovation and entrepreneurship model, teachers and students form learning communities to carry out flip classroom and sub-classroom teaching. Discipline competitions were used as carriers to guide students to carry out double creations practice in order to enhance students' ability of innovation and entrepreneurship.

"Four Platforms" is to build experimental teaching, comprehensive training, engineering design, innovative entrepreneurial multi-dimensional resources platform, in accordance with the principle of resource allocation and functional clusters, to set up a network interactive experimental teaching platform. We have developed 3 sets of virtual simulation training software, self-developed ethyl acetate school micro-factory to set up an intelligent and efficient comprehensive training platform. As a whole, we have built a national enterprise technology center, 20 practice bases to set up a school-enterprise co-construction engineering design platform. Moreover, we have built 15 innovation and entrepreneurship education bases to establish teacher-student linkage innovation entrepreneurial platform.

2.2.3. Guided by scientific evaluation, build a diversified evaluation system

On the subject of evaluation, transform from the single subject of the teacher to the joint subject of the teacher, enterprise personnel, group members and students. In the assessment content, the new mode focus on the ability of strengthening the chemical knowledge which learned in the classroom systematically application to practical work rather than the memory knowledge assessment. In the assessment method, we changed from one test to multiple exams to achieve comprehensive assessment and evaluation of knowledge, ability and quality.

3. Construct of a "Five-dimensional Force Drive" collaborative education system and safeguard mechanism 3.1. Joint training mechanism for sharing gain and risks

The applied chemistry major of Yancheng Teachers University explored and built a school-enterprise joint training mechanism based on the gain- and risk-sharing, and used both the educational environment and educational resources of the enterprise and school to adopt the joint training of intra-school training and off-campus training (cultured by enterprises, industry and research institutes). In this way of combination, experts from enterprise technicians and research institutes can also serve as practical teaching instructors, making full use of their professional knowledge and rich practical experience to jointly guide practical teaching, especially to guide practical training and practical teaching. Enterprises, industries and research institutes bear a certain amount of training costs, and the applied chemistry major tends to recommend excellent students to work in cooperative units, fully embodying the principle of sharing gain and risks.

\subsection{Power-driven mechanism based on real demand}

The applied chemistry major followed the dynamic relationship between the interests and responsibilities of mutual assistance and mutual benefit and explored a dynamic driving mechanism based on real needs to ensure the lasting cooperation between universities, local governments, enterprises, industries and research institutes. In such abovementioned cooperation, the five parties have achieved their respective goals: the applied of chemistry major in the collaborative education can improve the quality of applied talent cultivation, optimize the faculty structure, access to funding and realize the commercialization of scientific and technological achievements. The local government in the collaborative education can achieve the talents that meet the needs of economic and social development to meet the needs of local economic transformation and development for high-quality talents. On the side, the enterprises, industries and research institutes can achieve technical support to reduce manufacturing cost. In addition, in the cooperation, the five parties have institutionalized, scientific, standardized and long-term cooperation through the signing of various types of base cooperation agreements. 


\subsection{The multi-interaction mechanism with clear powers and responsibilities}

3.3.1. Established a feedback and consultation mechanism between the applied chemistry major and industry, enterprises and research institutes

Through the talent demand and quality information feedback from industry, enterprises and research institutes, the talent cultivation program has been adjusted to promote the construction of the applied chemistry major, adapting to the needs of industry, education and research. As a consequence, we can train high-quality talents to meet the needs of society and regional development.

3.3.2. Established a talent cultivation mechanism of the government and enterprises deep participation

In order to improve the quality of talent training, industry, enterprises and research institutes deeply participated in the training process and the set-up of training objectives, teaching plans, teaching content and training methods. 3.3.3. Established an exchange mechanism between the applied chemistry major and government, industry, enterprises and research institutes

Through the establishment of teachers and student incentive funds, and innovative R\&D projects in government, industry, enterprises, and research, communication between school and government, school and industry, school and enterprises, and school and research institutes have been promoted to improve the quality of applied talents.

\section{Form specific education modes under the "Five-dimensional Force Drive" collaborative education system} 4.1. School-local government cooperation mode

The applied chemistry major of Yancheng Teachers University signed a school-local governments cooperation agreement with Yancheng Binhai Chemical Industry Park. It adopted a market-oriented operation mode and established long-term cooperative relationships in personnel training, application development, technology exchange, and results transformation, and delivered a large number of first-line technical talents to Binhai Chemical Industry Park. Furthermore, the students' practical and innovative abilities and the quality of personnel training have been improved through school-local governments cooperation mode. In addition, around the local economic development needs of Yancheng city, the " expert + company + student " efficient technology service has been established to improve the ability to serve local economic development.

\section{2. "Board mode" of school-enterprise cooperation}

The applied chemistry major of Yancheng Teachers University constructed the basic system of running the board of directors, formed a relatively sound operating mechanism such as talent cultivation, teacher training and technology services under the mode of running the board of directors ${ }^{[5]}$. At present, there are 15 directors, which can fully meet the needs of students in the factory, such as factory internships, production internships, and graduation thesis. Various scholarships, such as professional scholarships, special student scholarships, and outstanding freshmen scholarships, provide a large number of opportunities for work-study. In addition, more than 50 scientific research cooperation projects have been carried out, more than 10 new technologies have been provided to the directors, and more than 10 new products have been jointly developed, generating more than 20 million yuan for enterprises. Through the cooperation of the board model, the strengths of both applied chemistry major and enterprises have been improved, making the scope of follow-up cooperation wider and deeper.

\section{Acknowledgments}

The research is supported by Jiangsu Higher Education Teaching Reform Research Project (2017JSJG209) and the Top-notch Academic Programs Project of Jiangsu Higher Education Institutions (PPZY2015B113).

\section{References}

[1] Yanfeng Guo, Feng Jiang, Xiaoyang Chen. (2018). Innovating Cooperation Mechanism, Improving the Quality of College Students' Education: Taking South China Agricultural University as an Example. Science and Technology Management Research, 22: 105-110.

[2] Yan-Liang Chen, De-Li Li. (2018). Practice and Model Construction of Collaborative Education by Government, Industry and Higher Education Institutions from Perspective of Triple Helix Theory. Heilongjiang Researches on Higher Education, 292: 87-90.

[3] Hui-Qin Zhao, Xiao-Hui Chen. (2018). Research on the Multi-Dimension Cooperative Education Mode of Applied Universities in the Concept of Production-Education Integration-A Case Study of Digital Media Technology Specialty of Datong University of Shanxi. Theory and Practice of Education, 38:6-8.

[4] De-Yi Hen, Jun-Hong Li, Lei Zhang, Xi-Yan Xu. (2019). New Mode of Cooperation Education between School-Enterprise-Association in Construction Cost Specialty. Education Teaching Forum, 12: 32-33.

[5] Xiao-Chun Chen, Hong-Long Xu. (2019). Research and Practice of "Studio" Operation Mechanism Based on School-enterprise Collaboration. Education Teaching Forum, 12: 32-33. 